\title{
ANALISIS DESAIN DIDAKTIS SEGIEMPAT YANG DIKEMBANGKAN MENGGUNAKAN MODEL PEMBELAJARAN BERBASIS MASALAH
}

\author{
Eka Komalasari ${ }^{1}$, Sumarni $^{2}$, Nuranita Adiastuty ${ }^{3}$ \\ Universitas Kuningan $1,2,3$ \\ Email: sumarni@uniku.ac.id², nuranita.adiastuty@uniku.ac.id ${ }^{3}$
}

\begin{abstract}
Abstrak. Penelitian ini dilatarbelakangi oleh hambatan belajar yang dialami siswa terkait materi segiempat. Berdasarkan hal tersebut maka tujuan dari penelitian ini yaitu: (a)menganalisis desain didaktis yang telah disusun guru model pada materi segiempat dengan menggunakan model problem-based learning; (b)menganalisis dugaan hambatan belajar yang diduga muncul kembali pada desain didaktis yang disusun oleh guru model; dan (c)membuat usulan untuk desain didaktis awal yang bertujuan untuk mengatasi dugaan hambatan belajar yang muncul kembali. Subjek dalam penelitian ini adalah guru model (Kiki Okatviani) dan desain didaktis materi segiempat dengan model pembelajaran berbasis masalah (PBL). Penelitian ini menggunakan metode kualitatif dan model penelitian Didactical Design Research (DDR) yang terdiri dari tiga tahapan yaitu: (a) prospective analysis; (b)metapedadidactic analysis; dan (c)retrospective analysis. Teknik pengumpulan data dalam penelitian ini menggunakan teknik triangulasi (wawancara, observasi, dan studi dokumentasi). Untuk teknik analisis data menggunakan gabungan dari metode kualitatif dan model DDR dimana kegiatannya adalah: (a)Prospective Analysis atau analisis data dengan melakukan wawancara kepada guru model terkait desian didaktis yang disusun pada materi segiempat; (b)Metapedadidactic Analysis kegiatan menganalisis desain didaktis, menganalisis dugaan munculnya hambatan belajar dari desain didaktis, dan pemberian usulan untuk mengatasi hambatan belajar yang muncul; dan (c)Retrospective Analysis, pada tahap ini peneliti membuat kesimpulan mengenai desain didaktis yang telah dianalisis. Hasil penelitian ini menyimpulkan bahwa desain didaktis yang disusun oleh guru model sudah sesuai dan dapat digunakan pada kegiatan pembelajaran, adapun kesalahan yang ditemukan dalam desain didaktis yaitu didactical learning obstacle dapat diperbaiki sesuai usulan yang diberikan oleh peneliti, agar siswa tidak mengalami hambatan dalam proses pembelajaran.
\end{abstract}

\section{Kata Kunci: Analisis Desain Didaktis, Segi Empat, Didactical Design Research, Learning Obstacle, Problem-Based Learning}

\begin{abstract}
This research is motivated by the learning barriers experienced by students related to the rectangular material. Based on this, the objectives of this study were: (a) to analyze the didactic design that the teacher had compiled on the rectangular material using the problem-based learning model; (b) analyzing the alleged learning barriers that allegedly reappeared in the didactic design prepared by the model teacher; and (c) make proposals for an initial didactic design aimed at overcoming the alleged recurring barriers to learning. The subjects in this study were the model teacher (Kiki Okatviani) and the didactic design of the rectangular material with the problembased learning model (PBL). This study used qualitative methods and the Didactical Design Research (DDR) research model which consisted of three stages, namely: (a) prospective analysis; (b) metapedadidactic analysis; and (c) retrospective analysis. Data collection techniques in this study used triangulation techniques (interviews, observation, and study documentation). For data analysis techniques using a combination of qualitative methods and DDR models where the activities are: (a) Prospective Analysis or data analysis by conducting interviews with model teachers related to didactic designs arranged on rectangular material; (b) Metapedadidactic Analysis, the activity of analyzing didactic designs, analyzing the alleged emergence of learning barriers from didactic designs, and providing suggestions for overcoming learning barriers that arise; and (c) Retrospective Analysis, at this stage the researcher makes conclusions about the didactic design that has been analyzed. The results of this study concluded that the didactic design prepared by the model teacher was appropriate and can be used in learning activities, while the errors found in the didactic design, namely didactical learning obstacle, can be corrected according to the suggestions given by the researcher, so that students do not experience obstacles in the learning process.
\end{abstract}

Keywords: Didactic Design Analysis, Quadrilateral, Didactical Design Research, Learning Obstacle, Problem-Based Learning 


\section{A. Pendahuluan}

Penyelenggaraan Sistem Pendidikan Nasional dilakukan dengan tiga jalur yaitu secara formal, informal dan non formal (Depdiknas, 2003). Pada pendidikan jalur formal, didalamnya terdapat pelajaran matematika, dimana untuk pelajaran matematika merupakan salah satu materi pembelajaran yang tidak hanya bertujuan untuk mencerdaskan siswanya saja, tetapi pembelajaran matematika diharapkan mampu membentuk kepribadian siswa untuk bersikap jujur, disiplin, bertanggung jawab, mampu berpikir kritis, sistematis, logis, dan kreatif. Matematika adalah salah satu pelajaran yang memiliki waktu pembelajarannya cukup lama, tetapi pada kenyataannya walaupun siswa sering bertemu dengan matematika masih saja matematika ini adalah mata pelajaran yang dianggap sulit oleh hampir semua siswa Indonesia. Pada saat ini masih sangat banyak siswa yang mengalami kesulitan belajar matematika karena menganggap bahwa matematika adalah pelajaran yang menakutkan, membosankan, tidak terlalu berguna didalam kehidupan, membebankan siswa karena keabstrakannya dan penuh dengan angka-angka serta rumus di setiap materinya.

Salah satu materi yang penting pada pembelajaran matematika adalah Geometri. Geometri melengkapi individu atau siswa dengan keterampilan seperti halnya pemecahan masalah, berpikir kritis, penalaran dan keterampilan untuk berpikir tingkat tinggi. Menurut Van de Walle (Evayanti 2013) geometri pada awalnya merupakan materi yang pada bab bahasannya sering dilewatkan atau penyampaian materinya diakhir tahun ajar. Tetapi pada sekarang ini geometri adalah bagian dari kurikulum disemua daerah dan negara. Walaupun geometri merupakan materi yang harus dikuasai oleh siswa tetapi pada pembelajarannya geometri merupakan pelajaran yang masih dapat membuat siswa mengalami kesulitan. Kesulitan tersebut adalah penguasaan konsep-konsep kunci dalam geometri dan belajar geometri tanpa mengalami terminologi dasar (Halat, 2008). Sejalan dengan kesulitan yang dikemukakan sebelumnya, ada pula kesulitan matematika yang diungkapkan oleh Burger \& Shaugnessy (1986) dimana siswa memiliki kesulitan dalam mengidentifikasi gambar dan pembuktian suatu teorema pada bangun dalam pembelajaran geometri. Pada penelitian ini, bidang geometri yang dibahas ada pada sub materi segiempat, dimana materi segiempat merupakan salah satu materi yang sering dijadikan bahan penelitian pada bidang keterampilan geometri. Untuk pengertian dari segiempat adalah bangun datar yang terbentuk dari empat ruas garis dan empat titik sudut sehingga dinamakanlah segiempat. Segiempat diajarkan pada siswa SMP khususnya kelas VII. Pada materi segiempat ini pembelajarannya adalah dengan pembahasan luas dan keliling segiempat.

Pada sub materi segiempat ini yang menjadi pembahasan adalah pengukuran luas dan keliling, yang merupakan salah satu sub materi yang harus sangat dikuasai oleh siswa karena pengaplikasiannya dapat berupa masalah sehari-hari seperti soal-soal kontekstual yang memerlukan kemampuan representasi dalam penyelesaiannya. Gagasan terkait representasi matematis di Indonesia telah ada dalam tujuan pembelajaran matematika dalam Permen No.23 Tahun 2006. Brousseau (2002) mengatakan pendapatnya yang berisi bahwa pengetahuan tidak hanya ditransfer dari satu orang saja, melainkan individu yang belajar harus dapat membangun pengetahuannya sendiri. Melanjutkan pendapat Brousseau, peneliti beranggapan bahwa siswa harus diberikan latihan-latihan diluar jam pelajaran matematika (disekolah) yang bertujuan agar siswa mampu menggali sendiri kemampuan pemecahan masalahnya. Dengan pengerjaan rutin ini diharapkan siswa akan terbiasa dengan pembelajaran matematika, dan akan terbiasa juga dengan soal-soal yang diberikan, baik soal yang baru dan mudah ataupun soal yang jarang ditemkan dan sulit. Wahyudin (2008) menyatakan perlunya memahami serta mampu menggunakan matematika dalam kehidupan sehari-hari dan di dunia kerja. Sama halnya dengan pendapat peneliti, bahwa matematika khususnya materi luas dan keliling bangun datar segiempat ini adalah mata pelajaran pokok disekolah dan materi luas dan keliling segiempat ini juga memiliki fungsi dunia luar. Sehingga peneliti berharap siswa mampu menghubungkannya atau mengaplikasikan pembelajaran luas dan keliling bangun datar 
segiempat dengan dunia nyata atau secara kontekstual. Contoh kontekstualnya adalah seorang pembuat pintu atau jendela memperkirakan ukuran luas dan keliling yang sesuai dengan ukuran pintu atau jendela pada umumnya. Penyesuaian ini pastinya melalui kegiatan perhitungan yang menggunakan rumus luas dan keliling salah satu bentuk bangun datar yang menyerupai bentuk pintu atau jendela yang hendak dibuat.

Pada penelitiannya, peneliti mengkaji situasi pembelajaran matematika pada materi luas dan keliling bangun datar segiempat. Langkah awal pada penelitian ini, peneliti memberikan studi pendahuluan berupa tes denga soal segiempat untuk siswa kelas VIII yang sudah pernah mempelajari materi segiempat. Tetapi dilihat dari hasil jawaban siswa masih sangat banyak kekurangan dalam mengerjakan soal tersebut, kekurangan tersebut diantaranya yaitu saat diberi soal siswa mengeluh tidak bisa dan lupa rumus dari materi segiempat, ada juga siswa yang asalasalan menjawab dengan caranya sendiri dengan mengacu pada rumus tetapi masih tetap salah dikarenakan salah konsep atau kekeliruan rumus, dan bahkan ada yang hanya menyelesaikan sebagian soal dan sebagian lainnya dibiarkan kosong. Dari hasil studi pendahuluan ini dapat dilihat bahwa siswa belum sepenuhnya paham terhadap materi segiempat. Ketidakpahaman ini berdampak pada kecilnya nilai siswa dalam pembelajaran materi segiempat. Menurut Asrori (Nurrahmi 2014) pelajaran matematika adalah pelajaran tidak disukai siswa sehingga pelajaran matematika sering dianggap sebagai pelajaran yang sulit. Kurangnya motivasi ini juga terjadi pada siswa kelas VIII, dimana siswa mengeluh bahwa sudah lupa materi segiempat yang sudah pernah dipelajari sehingga saat diberikan studi pendahuluan berupa soal segiempat siswa merasa sangat kesulitan, kesulitan inilah yang kemudian dapat memunculkan hambatan belajar terhadap siswa. Suryadi (2010) pun mengatakan bahwa hambatan yang sering dialami siswa adalah pada saat diberikan soal-soal identik yang kemudian diubah sedikit saja bentuknya disebut hambatan epistimologis (epistimilogical obstacle) disini siswa akan sangat kesulitan dalam menyelesaikan soal tersebut. Adapun penjelasan terkait jenis-jenis hambatan belajar menurut Brousseau (2002) terdapat tiga jenis learning obstacle (LO) diantaranya sebagai berikut : (1) Ontogenic Learning Obstacle merupakan hambatan belajar yang terjadi dikarenakan keterbatas dari siswa dalam pengembangan dirinya atau bisa juga dari segi kesiapan mentalnya. Misalnya anak usia dini belum siap apa bila mempelajari hal-hal yang rumit sehingga tidak akan ada materi yang di pahami; (2) Epistemology Learning Obstacle menurut D'Amore (2008) adalah seperangkat keyakinan, pengetahuan pribadi dan pengetahuan yang dimiliki masyarakat. Sedangkan menurut Duroux (Suryadi, 2011) hambatann epistemologis adalah pengetahuan seseorang yang terbatas pada konteks tertentu. Sehingga berdasarkan pendapat para ahli tadi dapat dikatakan baha hambatan epistemologis (Epistemology Learning Obstacle) adalah pengetahuan yang didasarkan pada apa yang dimilikinya (siswa) sehingga terbatas pada konteks tertentu saja; dan (3) Didactical Learning Obstacle adalah hambatan belajar yang muncul karena metode, pendekatan atau bahan ajar yang digunakan oleh guru kurang mendukung. Dari penjelasan learning obstacle di atas, learning obstacle yang diteliti oleh peneliti adalah jenis didactical learning obstacle dan epistemology learning obstacle. Dimana didactical learning obstacle atau hambatan belajar yang disebabkan karena kekurangan pada bahan ajar yang disusun oleh guru sejalan dengan kegiatan peneliti yaitu menganalisis desain didaktis atau bahan ajar yang disusun oleh guru model sedangkan untuk epistemology learning obstacle adalah kesulitan belajar siswa yang disebabkan oleh keterbatasan pengetahuan hanya pada suatu konteks tertentu saja Desain didaktis yang telah disusun tersebut adalah RPP dan LKPD pada materi segiempat dengan menggunakan model pembelajaran problem-based learning. Untuk ontogenic learning obstacle tidak diteliti oleh peneliti karena desain didaktis tidak diimplementasikan, jadi peneliti tidak bisa melihat kondisi mental siswa pada saat diberikan pembelajaran materi segiempat.

Dari hasil uraian di atas, hasil kegiatan studi pendahuluan tersebut ternyata tidak sesuai dengan harapan guru model dan peneliti, selain itu peneliti juga merasa bahwa siswa masih 
banyak yang bingung dengan sebuah soal baru yang bentuknya berbeda dari contoh yang sudah dibahas sebelumnya.Ternyata terdapat beberapa masalah yang dihadapi oleh siswa, dan untuk mengatasi masalah tersebut guru model (Kiki Oktaviani) membuat desain didaktis dalam bentuk bahan ajar Rencana Pelaksanaan Pembelajaran (RPP) yang dilengkapi dengan Lembar Kerja Peserta Didik (LKPD) dengan menggunakan model problem-based learning. Menurut Mulyasa (Zakaria, 2016) RPP merupakan suatu rencana yang didalamnya menggambarkan prosedur dan manajemen pembelajaran yang digunakan untuk mencapai kompetensi dasar yang digunakan dalam standar isi dan dijabarkan pada sebuah silabus. Sedangkan LKPD menurut Prastowo (Kurniawan, 2015) yaitu suatu bahan ajar yang dicetak dan bentuknya adalah lembaran-lembaran yang berisikan materi, ringkasan, serta petunjuk yang harus dilaksanakan oleh siswa. Sedangkan untuk model pembelajaran PBL dimana didalam kegiatan pembelajarannya terdiri dari 5(lima) langkah sebagai berikut: (1)mengorientasikan siswa kepada masalah; (2)mengorganisasikan siswa untuk belajar; (3)membimbing penyelidikan siswa baik secara individu atau kelompok; (4)mengembangkan dan menyajikan hasil karya; dan (5)menganalisis dan mengevaluasi proses pemecahan masalah. Dimana tahapan ini sesuai dengan pendapat Trianto (Rusman, 2012). Sehingga desain didaktis yang dibuat oleh guru model diharapkan dapat mengatasi masalah yang dialami siswa dan menjadikan penyampaian materi segiempat lebih menyenangkan dan mudah diterima oleh siswa.

Pada penelitian ini, peneliti menganalisis desain didaktis yang telah disusun oleh guru model. Analisis desain didaktis disini yaitu mengamati desain didaktis yang dibuat oleh guru model berupa RPP dengan model problem based-learning dan LKPD untuk pembelajaran materi segiempat. Desain didaktis tersebut pun menggunakan model pembelajaran berbasis masalaha atau model problem-based learning. Model problem-based learning ini membentuk kegiatan pembelajaran yang membiasakan siswanya dihadapkan pada masalah-masalah nyata atau masalah kontekstual. Problem-based learning juga memudahkan siswa dalam belajar karena kegiatan berkelompok sehingga apabila siswa merasa sungkan bertanya kepada guru, siswa dapat bertanya kepada teman kelompoknya yang dianggap lebih paham terhadap materi yang sedang dipelajari. Sejalan dengan apa yang dikatakan oleh Choridah (2013) bahwa pembelajaran berbasis masalah ini adalah suatu pembelajaran kooperatif yang akan membuat siswa lebih mudah dalam menemukan dan memahami konsep yang sulit dengan kegiatan siswa yang saling berdiskusi dengan temannya terkait masalah yang dihadapi. Selain itu menurut Abuddin (Wulansari,2017) model pembelajaran Problem-Based Learning akan membuat siswa terbiasa menghadapi masalah dan mampu untuk memecahkan permasalahan tersebut, dan dapat menggunakannya pada kehidupan sehari-hari khususnya dikalangan masyarakat apabila menghadapi permasalahn yang sesungguhnya.

Berdasarkan uraian di atas, peneliti memiliki tujuan yang hendak dicapai dalam penelitian ini, adapun tujuan tersebut adalah: (1) Menganalisis desain didaktis materi segiempat dengan model problem-based learning yang telah disusun oleh guru model; (2) Menganalisis hambatan belajar atau learning obstacle yang muncul pada saat kegiatan pembelajaran segiempat dengan menggunakan desain didaktis yang telah disusun oleh guru model; dan (3) Membuat usulan desain didaktis untuk mengatasi dugaan hambatan belajar yang muncul dalam pembelajaran segiempat yang telah disusun oleh guru model.

\section{B. Metodologi Penelitian}

Untuk penelitian ini, peneliti menggunakan metode kualitatif dengan gabungan model Didactical Design Research (DDR). adapun untuk metode kualitatif terdiri dari wawancara, observasi, dan studi dokumentasi. Sedangkkan untuk model Didactical Design Research (DDR) terdiri dari tiga tahapan yaitu: (1) Analisis prospektif (sebelum pembelajaran); (2) Analisis metapedidaktik; dan (3) Analisis retrosfektif (hasil gabungn analisis prospektif dan analisis metapedidaktik). Untuk pemaparan ketiga tahapan tersebut dijelaskan sebagai berikut: 


\section{Analisis prospektif}

a. Menentukkan materi pembelajaran matematika yang akan dijadikan bahan penelitian yaitu konsep luas dan keliling segiempat.

b. Melakukan kegiatan rekontekstualisasi atau tahapan peneliti dalam mengumpulkan data dengan cara melakukan tes studi pendahuluan kepada siswa kelas VIII yang pernah menerima pelajaran terkait konsep luas dan keliling segiempat.

2. Analisis metapedidactic

a. Menganalisis desain didaktis berdasarka hasil wawancara kepada guru model terkait bahan ajar tersebut berdasarkan learning trajectory serta perangkat pembelajarannya yaitu RPP dan LKPD.

b. Menganalisis perangkat pembelajaran atau bahan ajar yang telah disusun untuk memperoleh kemungkinan munculnya hambatan belajar yang siswa alami dalam menggunakan desain didaktis yang telah dikembangkan guru model.

3. Analisis retrosfektif

a. Melakukan kegiatan rekonstruksi terhadap tahapan desain didaktis awal untuk membuat desain didaktis perbaikan berdasarkan dari hasil analisis dugaan hambatan belajar siswa.

Waktu penelitian ini dilaksanakan pada tahun 2020 dengan subjek penelitian yaitu guru model (Kiki Oktaviani) dan desain didaktis RPP dan LKPD dengan model PBL. Untuk guru model adalah subjek yang menyusun desain didaktis materi segiempat, sedangkan untuk desain didaktis adalah bahan ajar berupa RPP dan LKPD yang telah disusun oleh guru model yang memuat materi pembelajaran segiempat dengan menggunakan model PBL. Pada subjek guru model (Kiki Oktaviani) dilakukan wawancara berupa pertanyaan terkait perancangan desain didaktis yang disusunnya, sedangkan untuk desain didaktis yang telah disusun oleh guru model (Kiki Oktaviani) dalam bentuk RPP dan LKPD dengan menggunakan model PBL yang terdiri dari 4 pertemuan dengan materi yang diajarkan adalah materi segiempat yang kemudian dianalisis setiap pertemuannya dengan tujuan untuk mengetahui apakah desain didaktis yangtelah tersusun tersebut sesuai tidaknya dengan tujuan dari hasil wawancara dengan guru model sebelumnya, untu mengetahui hambatan belajar apa yang mugkin dapat muncul dari desain didaktis tersebut, dan memberikan usulan terhadap hambatan belajar yag ditemukan dari desain didaktis tersebut.

Kegiatan pengumpulan data dilakukan secara langsung oleh peneliti sehingga instrumen penelitian yang digunakan adalah peneliti sendiri dan dilengkapi dengan instrumen lainnya. Instrumen penelitan yang disusun sendiri oleh peneliti adalah berupa teks pedoman wawancara yang sebelumnya telah divalidasikan kepada dua validator yaitu dosen pendidikan matematika dan dosen pendidikan bahasa dan sastra indonesia. Untuk pedoman wawancara ini dibuat berdasarkan perspektif Learning Trajectory (LT) atau rancangan bahan ajar yang di buat oleh guru model yaitu berupa RPP dan LKPD dan berikut adalah teks pedoman wawancara yang dipakai: 
Tabel 1 Teks Pedoman Wawancara

\begin{tabular}{|c|c|c|}
\hline Teori & No. & Pertanyaan \\
\hline \multirow{7}{*}{$\begin{array}{c}\text { Learning } \\
\text { Trajectory (LT) }\end{array}$} & 1. & $\begin{array}{l}\text { Apa tujuan dari pembelajaran materi bangun datar segi } \\
\text { empat pada sub bahasan konsep luas dan keliling yang akan } \\
\text { dilaksanakan tersebut? }\end{array}$ \\
\hline & 2. & $\begin{array}{l}\text { Materi prasyarat apa saja yang harus dikuasai oleh } \\
\text { siswa sebelum mempelajari materi bangun datar segi empat? }\end{array}$ \\
\hline & 3. & $\begin{array}{l}\text { Apakah pada pembelajaran materi bangun datar segi } \\
\text { empat ini, ibu menggunakan alat bantu seperti buku } \\
\text { pedoman matematika atau media lainnya? }\end{array}$ \\
\hline & 4. & $\begin{array}{l}\text { Mengapa ibu memilih model atau pendekatan } \\
\text { problem-based learning dalam kegiatan penyampaian materi } \\
\text { bangun datar segi empat? }\end{array}$ \\
\hline & 5. & $\begin{array}{l}\text { Seperti apa alur pembelajaran materi bangun datar segi } \\
\text { empat dengan menggunakan model problem-based learning } \\
\text { dan perangkat pembelajaran (RPP dan LKPD) yang ibu } \\
\text { pakai? }\end{array}$ \\
\hline & 6. & $\begin{array}{l}\text { Apakah ibu kesulitan dalam mempersiapkan } \\
\text { perangkat atau desain pembelajaran yang akan ibu gunakan? } \\
\text { jika iya, kesulitan seperti apa yang ibu alami? }\end{array}$ \\
\hline & 7. & $\begin{array}{l}\text { Apakah perangkat atau desain pembelajaran yang ibu } \\
\text { buat dapat mengatasi hambatan belajar dan membatu siswa } \\
\text { dalam mempelajari materi segi empat? }\end{array}$ \\
\hline
\end{tabular}

Selanjutnya untuk instrumen pengumpulan data lainnya ada observasi yaitu kegiatan peneliti dalam menganalisis secara langsung desain didaktis yang telah disusun oleh guru model dalam bentuk RPP dan LKPD dengan menggunakan model problem-based learning. Selanjutnya instrumen pengumpulan data yang terakhir adalah studi dokumentasi dimana dokumentasi yang dimaksud adalah pengumpulan bahan ajar atau perangkat pembelajaran dalam bentuk RPP dan LKPD sebagai bukti kegiatan analisis yang dilakukan oleh peneliti. Pada saat kegiatan pengumpulan data, peneliti dibantu dengan alat elektronik berupa handphone dikarenakan adanya pandemi yang tidak memungkinkan peneliti mengumpulkan data secara langsung. Penggunaan handphone ini adalah saat kegiatan wawancara antar peneliti dengan guru model.

Analisis data pada penelitian ini adalah gabungan antara metode kualitatif dengan model Didactical Design Research (DDR). Selain itu kegiatan untuk analisis data kualitatif dimulai sejak awal pengumpulan data. Adapun hal yang dilakukan pada kegiatan analisis data kualitatif ini menjadi kegiatan yang berlangsung secara berulang dan terus-menerus. Analisis data tersebut berkaitan dengan kegiatan mengakomodasi data yang telah didapat lalu kemudian menyajikan hasilnya terkait hal penting yang muncul dalam kegiatan penelitian yang dilakukan. Kegiatan ini hampir sama dengan penjelasan dari Miles \& Huberman (1994) untuk setiap kegiatan analisis data diantaranya adalah sebagai berikut : (a) Kegiatan mereduksi data yang merupakan proses memilih dan menentukan data yang berlangsung ketika mulai pengumpulan data. Data dipilih berdasarkan dari tujuan penelitian yang sebelumnya telah ditetapkan maka diperlukan penyaringan data atau informasi antara yang relevan dengan yang tidak relevan; (b) Kegiatan penyajian data merupakan kegiatan pendeskripsian data yang telah disusun yang kemudian akan ditarik kesimpulan. Data penelitian disajikan dalam bentuk deskriptif, dan untuk data penelitian terkait konsep luas dan keliling segiempat dan pengembangan desain didaktisnya disajikan dalam bentuk kualitatif; dan (c) Kegiatan penarikan kesimpulan merupakan kegiatan tahap akhir dalam penelitian kualitatif dimana kegiatan ini berdasarkan dari data yang telah didapat di lapangan. Selain dari kegiatan analisis data di atas, pada 
penelitian desain didaktis (Didactical Design Research) ini pun ada tahapan seperti Prospective Analysis, Metapedadidactic Analysis, dan Retrospective Analysis, dimana data yang dikumpulkan berupa data dugaan munculnya hambatan belajar yang dianalisis dari desain didaktis materi segiempat dengan kegiatan wawancara, observasi, dan studi dokumentasi.

Pada tahap pertama yaitu Prospective Analysis, analisis data yang dilakukan adalah dengan kegiatan wawancara kepada guru model terkait desian didaktis atau bahan ajar yang disusun dan digunakan saat pembelajaran materi segiempat. Kegiatan wawancara ini dilakukan dengan bantuan alat elektronik yaitu handphone, dimana handphone tersebut digunakan untuk merekam pembicaraan peneliti dengan guru model. Setelah melakukan wawancara, selanjutnya peneliti menganalisis desain didaktis terkait meteri segiempat dan hasil dari wawancara yang telah dilakukan tersebut. Kemudian pada tahap kedua anailsisi data yaitu tahap Metapedadidactic Analysis, peneliti melakukan analisis desain didaktis yang sebelumnya telah disusun oleh guru model, menganalisis dugaan munculnya hambatan belajar atau learning obstacle dari desain didaktis yang telah disusun, dan pemberian usulan untuk memperbaiki kesalahan yang dapat memunculkan hambatan belajar pada desain didaktis yang telah disusun tersebut. Selanjutnya pada tahap terakhir yaitu tahap Retrospective Analysis, dimana pada tahap ini peneliti membuat kesimpulan terkait desain didaktis yang telah dianalisis sebelumnya. Kemudian setelah itu membuat usulan untuk desain didaktis materi segiempat berdasarkan kegiatan analisis yang telah dilakukan, guna mengurangi hambatan belajar yang dialami oleh siswa.

\section{Hasil Penelitian dan Pembahasan}

1. Desain didaktis segiempat dengan model problem-based learning yang telah disusun oleh guru model

Pada penelitian ini desain didaktis yang disusun oleh model berupa RPP dan LKPD dengan menggunakan model problem-based learning langkah awal yang dilakukan oleh peneliti adalah wawancara kepada guru model (Kiki Oktaviani) dengan menggunakan pedoman wawancara yang telah disusun dan pada kegiatan selanjutnya peneliti melakukan analisis hasil wawancara dan desain didaktis yang telah disusun meninjau kesesuaian dan harappan guru model untuk mengatasi hambatan belajar siswanya.

Berdasarkan hasil wawancara yang telah dilakukan oleh peneliti dengan guru model (Kiki Oktaviani), hasil wawancara tersebut menjelaskan bahwa pembelajaran pada materi bangun datar segiempat dengan desain didaktis yang disusun oleh guru model memiliki tujuan untuk mengenalkan macam-macam bangun datar segiempat kepada siswa, membuat siswa memahami sifat-sifat bangun datar segiempat, membuat siswa mengetahui rumus luas dan keliling yang ada pada setiap bangun datar segiempat, dan membuat siswa dapat memanfaatkan ilmu dari materi bangun datar segiempat di dunia pendidikan dan dunia nyata atau kehidupan sehari-hari. Sebagai contohnya, misalkan ada seorang siswa yang ingin menghitung luas dan keliling dari pintu rumahnya maka siswa tersebut dapat menggunakan rumus luas dan keliling dari salah satu rumus yang ada pada bangun datar segiempat yang tentunya disesuaikan dengan bentuk pintu rumahnya (berbentuk persegi panjang atau bentuk segiempat lainnya). Sejalan dengan pendapat yang dikemukakan oleh Fitriyani, Widodo dan Hendrianto (2018) bahwa: Pembelajaran geometri dapat melatih kemampuan logika, sistematika, dan berpikir kreatif siswa. Keterampilan seperti itu sangat diperlukan untuk mempelajari cabang matematika lainnya serta untuk memecahkan masalah dalam kehidupan sehari-hari.

Berdasarkan penjelasan di atas dapat disimpulkan bahwa guru model ingin siswanya memahami materi segiempat sebagai salah satu materi wajib dalam dunia pendidikan dan selain itu juga materi segiempat ini merupakan materi yang dapat membantu dikehidupan nyata seperti yang dicontohkan di atas sehingga selain disekolah pun siswa dapat mengaplikasikan materi pembelajarannya didunia nyata yang memiliki banyak manfaat. Selain itu, ada pula 
pembahasan terkait alur atau langkah pembelajaran yang tertulis di dalam perangkat pembelajaran dalam bentuk RPP dan LKPD yang disusun oleh guru model. Untuk

alur pembelajaran dibagi lagi menjadi tiga kegiatan yaitu kegiatan pendahuluan, kegiatan inti, dan kegiatan penutup. Pada kegiatan inti guru model menyesuaikan dengan langkah pembelajaran model PBL, dimana langkah pembelajarannya ada: (1) mengorientasikan siswa kepada masalah; (2) mengorganisasikan siswa menjadi kelompok; (3) membimbing penyelidikan siswa baik secara individu atau kelompok; (4) mengembangkan dan menyajikan hasil karya; dan (5) menganalisis dan mengevaluasi proses pemecahan masalah. Dimana tahapan problem-based learning tersebut dikemukakan oleh Trianto (Rusman,2012).

Pada kegiatan pembelajaran dengan menggunakan model problem-based learning ini , siswa lebi mendominasi kegiatan pembelajaran dibandingkan guru, dan peran guru hanya menjadi fasilitator dan membenarkan pendapat siswa yang kurang sesuai. Pada penelitian miliki Nurroniah (2014) pun mengatakan dalam penelitiannya bahwa dalam prakteknya pengajar bertindak sebagai seorang fasilitator, dimana artinya bahwa pengajar atau guru tidak harus selalu mengikuti isi yang terdapat atau tertulis dalam buku teks yang kadang isi tersebut tidak sesuai dengan kondisi kelas yang akan menerima pembelajaran. Selain itu model problembased learning pun memungkinkan siswa untuk mengaitkan materi pembelajaran disekolah dengan masalah dikehidupan nyata karena kegiatan pembelajaran dengan model problem-based learning ini dimulai dari mengingat kembali materi prasyarat sampai dengan membuat kesimpulan dari kegiatan pembelajaran yang telah dilaksanakan. Adapun pemberian tugas rumah yang diberikan guru model adalah sebagai latihan siswa untuk lebih memahami materi segiempat.

Untuk kegiatan analisis desain didaktis yang telah disusun oleh guru model, peneliti menganalisis RPP dengan memperhatikan komponen -komponen yang harus ada dalam RPP dan LKPD dimana dalam RPP ada identitas, keterangan KI, KD, IPK, Tujuan pembelajaran, materi pembelajaran, metode pembelajaran, media pembelajaran, sumber belajar, langkahlangkah pembelajaran, penilaian hasil belajar, dan instrumen penilaian hasi belajar. Menurut peneliti untuk desain didaktis susunan guru model ini, sudah sesuai dan sudah dapat digunakan dalam kegiatan pembelajaran dikarenakan dari hasil analisis dengan memperhatikan komponen RPP dianggap sudah terdapat dialam RPP. Adapun untuk LKPD disana terdapat identitas LKPD, petunjuk penggunaan LKPD, Kompetensi Dasar (KD), IPK dan tujuan pembelajaran. Setelah itu diberikan soal-soal untuk didiskusikan oleh siswa dalam bentuk kelompok, kemudian kegiatan terakhir ada latihan soal sebagai evaluasi siswa yang dikerjakan secara individu.

2. Dugaan hambatan belajar atau learning obstacle pada saat kegiatan pembelajaran segiempat dengan menggunakan desain didaktis yang telah disusun oleh guru model Untuk dugaan hambatan belajar yang ditemukan dari hasil analisis sebelumnya, ditemukan didactical learning obstacle atau hambatan belajar yang disebabkan karena bahan ajar yang disusun oleh guru kurang sesuai dengan kegiatan pembelajaran yang dilaksanakan. Adapun hambatan belajar tersebut disebabkan karena: (1)Pada pembahasan RPP dan LKPD pertemuan pertama tidak ditemukan hambatan belajar; (2)Pada pembahasan RPP pertemuan kedua ditemukan kesalahan pada bagian identitas RPP dimana guru model tidak menuliskan secara lengkap sub bahasan apa yang akan diajarkan pada pertemua kedua ini, bentuk dari sub materi yang dituliskan guru model hanya rumus luas dan keliling segiempat, tidak dijelaskan segiempat apa yang dibahas. Ada baiknya bahwa keterangan sub materi menjadi rumus luas dan keliling segiempat (persegi dan persegi panjang) karena dianggap lebih jelas. Kemudian ada kesalahan pada instrumen penilaian hasil belajar dimana terdapat soal dengan keterangan bahwa soal tersebut menunjukan gambar tetapi gambar yang dimaksud tidak dicantumkan. Kemudian kesalahan serupa pun ada dalam LKPD karena soal latihan dalam LKPD sama denga soal yang ada pada instrumen penilaian hasil belajar; (3)Pada pembahasan RPP dan LKPD 
pertemuan ketiga, ditemukan kesalahna yaitu pada identitas RPP bagian sub materi dimana sub materi hanya tertulis rumus las dan keliling segiempat tanpa disertaan segiempat apa yang hendak dibahas, sebaiknya untuk sub materi diperbaiki menjadi rumus luas dan keliling segiempat (jajargenjang dan trapesium), ada juga kesalahan pada instrumen penilaian hasil belajar dimana diberikan soal yang menjelaskan bangun datar jajargenjang memiliki luas $=2$ meter, sedangkan pada jawaban tertera bahwa 2 meter itu adalah sisi miring dari bangun jajargenjang, dan pada penjabaran jawaban luas $=6 \mathrm{~m} 2$. Dimana antara soal, apa yang diketahui, dan apa yang didapat dari jawaban ini tidak berkesinambungan satu sama lain. Kesalahan pada soal instrumen penialian hasil belajar ini pun ada pada kesalahan LKPD karena soal yang diberikan sama; dan (4)Pada pembahasan RPP dan LKPD pertemuan keempat ini hanya ditemukan kesalahan pada RPP saja bagian identitas RPP yaitu sub materi luas dan keliling segiempat, tidak dituliskan segiempat (belah ketupat dan layang-layang) yang dibahas pada pertemuan keempat tersebut dan untuk selebihnya tidak ditemukan kesalahan dalam RPP atau pun didalam LKPD.

3. Usulan desain didaktis untuk mengatasi dugaan hambatan belajar yang uncul dalam pembelajaran segiempat yang telah disusun oleh guru model.

Berdasarkan hasil analisis peneliti terhadap desain didaktis yang telah disusun, ternyata ditemukan beberapa kesalahan seperti yang dipaparkan di atas, kesalahan tersebut ditemukan khususnya pada bahan ajar RPP, dan kesalahan tersebut diduga dapat menimbulkan learning obstacle muncul kembali sehingga untuk mengatasinya peneliti memberikan beberapa usulan perbaikan untuk kesalahan-kesalahan yang sudah dibahas sebelumnya. Adapun pembahasan usulan untuk desain didaktis tersebut peneliti paparkan sebagai berikut: (1)Usulan untuk desain didaktis pertemuan pertama tidak ada usulan karena tidak ditemukan kesalahan didalam RPP dan LKPD dan dirasa sudah sesuai dan dapat digunakan untuk kegiatan pembelajaran; (2)Usulan untuk desain didaktis pertemuan kedua dalam RPP adalah perbaikan keterangan sub bahasan tambahkan segiempat yang akan di bahas yaitu persegi dan persegi panjang sehingga sub bahasan menjadi rumus luas dan keliling segiempat (persegi dan persegi panjang) kemudian untuk usulan kesalahan soal yang ada pada RPP dan LKPD sesuaikan kembali soal dengan gambar, apabila desain didaktis sudah dicetak maka lebih baik gambar yang tidak tercantum digambar secara manual dihalaman selanjutnya atau digambar manual di white board; (3)Usulan untuk desain didaktis pertemuan ketiga ada pada identitas RPP dimana kesalahan tersebut ada pada sub bahasan materi yang ditulis rumus luas dan keliling segiempat. Untuk kekurangan ini sebaiknya ditambahkan keterangan segiempat yang dipelajari yaitu jajargenjang dan trapesium. Sehingga sub bahasan materi menjadi rumus luas dan keliling segiempat (jajargenjang dan trapesium). Kemudian usulan untuk kesalahan soal dalam RPP dan LKPD adalah sesuaikan kembali soal dengan jawaban, dimana jika pada soal telah diketahui bahwa luas $=2$ meter dan ditanyakan luas dari sebuah kolam, maka jawaban yang harusnya dihasilkan yaitu 2 meter. Tetapi jika 2 meter tersebut adalah panjang dari sisi miring pada bangun jajargenjang, maka jawaban yang dihasilkan sudah benar yaitu $6 \mathrm{~m} 2$. Apabila ada keterangan soal yang salah penulisan sebaiknya diganti dengan ditulis ulang secara manual atau diinformasikan langsung pada siswa saat kegiatan pembelajaran berlangsung; dan (4)Usulan untuk desain didaktis pertemuan keempat adalah ada pada sub materi. Sehingga usulan yang peneliti berikan pun adalah sebaiknya untuk sub bahasan materi ditambahkan keterangan segiempat yang dipelajari yaitu belah ketupat dan layang-layang. Sehingga sub bahasan materi menjadi rumus luas dan keliling segiempat (belah ketupat dan layang-layang) dimana penambahan tersebut membuat sub materi lebih jelas. Apabila bahan ajar sudah dicetak, maka dapat dituliskan secara manual menambahkan dibagian samping sub materi yang ada.

\section{Kesimpulan}


Hasil penelitian terhadap desain didaktis yang telah disusun oleh guru model (Kiki Oktaviani) didapat kesimpulan diantaranya:

1. Berdasarkan hasil analisis yang dilakukan peneliti terhadap desain didaktis susunan guru model dalam bentuk RPP dan LKPD dengan jumlah pertemuan sebanyak 4(empat) pertemuan dengan pembagian sub materi sebagai berikut: (a)desain didaktis pertemuan pertama membahas sifat-sifat segiempat (persegi, persegi panjang, belah ketupat, jajargenjang, layang-layang, dan trapesium); (b)desain didaktis pertemuan kedua membahas rumus luas dan keliling segiempat (persegi dan persegi panjang); (c)desain didaktis pertemuan ketiga membahas rumus luas dan keliling segiempat (jajargenjang dan trapesium); dan (d)desain didaktis pertemuan keempat membahas rumus luas dan keliling segiempat (belah ketupat dan layang-layang). Dimana desain didaktis tersebut menggunakan langkah pembelajaran dari model problem-based learning yang terdiri dari 5(lima) langkah yaitu: (a)mengorientasikan siswa terhadap masalah; (b)mengorganisasikan siswa untuk belajar; (c)membimbing penyelidikan siswa secara kelompok atau individu; (d)mengembangkan dan menyajikan hasil karya; dan (e)menganalisis dan mengevaluasi proses pemecahan masalah. Sehingga dari hasil analisis desain didaktis tersebut diperoleh kesimpulan bahwa desain didaktis tersebut telah sesuai dengan sintaks problem-based learning untuk setiap pertemuannya;

2. Berdasarkan hasil analisis desain didaktis (RPP dan LKPD) dijelaskan juga dugaan munculnya hambatan belajar atau learning osbtacle pada setiap pertemuannya. Adapun dugaan hambatan belajar yang diduga muncul pada desain didaktis ini adalah hambatan belajar jenis didactical learning obstacle yaitu hambatan belajar yang muncul karena metode, pendekatan atau bahan ajar yang digunakan oleh guru kurang mendukung. Untuk kemunculan didactical learning osbtacle pada RPP pertemuan ke-2(dua), RPP pertemuan ke-3(tiga), dan RPP pertemuan ke-4(empat) dimana kesalahannya terletak pada identitas RPP bagian sub materi. Kemudian ada juga kesalahan lain pada RPP yaitu pada instrumen hasil penilaian belajar soal nomor 3(tiga) yang ada pada RPP pertemuan ke-2(dua), dan kesalahan instrumen hasil penilaian belajar beserta kunci jawabannya ada pada soal nomor 2(dua) RPP pertemuan ke-3(tiga). Selanjutnya untuk kesalahan dalam LKPD yang diduga dapat memunculkan didactical learning obstacle yaitu untuk LKPD pertemuan ke2(dua) soal latihan nomor 3(tiga), dimana informasi pada soal yang harus mengamati gambar tetapi gambar yang dimaksud tidak disertakan. Kemudian ada juga kesalahan pada LKPD pertemuan ke-3(tiga) latihan soal nomor 2(dua), dimana pada soal dijelaskan bahwa untuk panjang, luas dan tinggi sudah diketahui, kemudian yang ditanyakan pada soal adalah luas dan keliling, dimana jika diperhatikan kembali sebaiknya untuk luas tidak perlu ditanyakan karena sudah diketahui. Selain dari penjelasan didactical learning obstacle tadi, diduga terdapat hambatan belajar lain yang muncul tetapi tidak peneliti cantumkan karena seharusnya desain didaktis melalui kegiatan implementasi kepada siswa sehingga fungsi dari RPP dan LKPD lebih dapat dipertanggung jawabkan hasilnya, tetapi karena alasan tertentu maka desain didaktis ini tidak diimplementasikan tetapi dibandingkan dengan desain didaktis dari peneliti terdahulu. Berdasarkan hasil perbandingan tersebut peneliti menyatakan bahwa terdapat learning obstacle lain selain didactical leraning obstacle pada desain didaktis tersebut dan peneliti menduga learning obstacle tersebut adalah epistemology learning obstcale.

3. Untuk kesimpulan ketiga ada terkait usulan desain didaktis (RPP dan LKPD) yang telah disusun oleh guru model yang terdiri dari 4(empat) pertemuan dengan menggunakan model problem-based learning tersebut, dimana usulan desain didaktis yang diberikan adalah sebagai berikut: (a)Untuk desain didaktis pertemuan pertama tidak diberikan usulan karena peneliti sudah merasa bahwa desain didaktis tersebut sudah sesuai dengan ketentuan penyusunan desain didaktis (RPP dan LKPD); (b)Usulan untuk desain didaktis 
pertemuan kedua adalah, pada identitas RPP sebaiknya untuk sub materi dituliskan rumus luas dan keliling segiempat (persegi dan persegi panjang). Kemudian untuk usulan soal dengan petunjuk mengamati gambar tetapi gambar tersebut tidak dicantumkan adalah dengan menggambar kembali dihalaman selanjutnya atau diwhite board untuk gambar yang dimaksudkan. Usulan keseluruhan pada desain didaktis pertemuan kedua ini adalah guru model harus lebih teliti dalam menyusun desain didaktis dan biasakan juga memeriksa kembali desain didaktis yang telah disusunnya tersebut; (c)Untuk usulan yang diberikan pada desain didaktis pertemuan ketiga bagian RPP ada pada identitas RPP sub materi dimana sebaiknya diubah atau ditambahkan menjadi rumus luas dan keliling segiempat (jajargenjang dan trapesium), jadi tidak hanya rumus luas dan keliling segiempat saja. Selanjutnya untuk usulan soal pada RPP dan LKPD dimana sebelumnya kesalahan yang ditemukan adalah sama (karena soal yang dijadikan permasalahan adalah sama) yaitu informasi yang diberikan soal kurang sesuai dan untuk jawabannya pun tidak saling berkesinambungan sehingga sebaiknya sesuaikan kembali tujuan atau informasi yang tertulis dalam soal sehingga tidak membingungkan dan sesuaikan juga kunci jawaban soal yang bersangkutan sehingga didapat jawaban yang seharusnya (tidak berbeda); dan (d)Terakhir ada usulan untuk desain didaktis pertemuan keempat pada bagian identitas RPP sub materi disana hanya tertulis rumus luas dan keliling segiempat, ada baiknya dijelaskan juga segiempat apa yang dibahas sehingga sub materi menjadi rumus luas dan keliling segiempat (belah ketupat dan layang-layang). Sedangkan untuk usulan LKPD tidak ada karena pada analisis kesalahan desain didaktis sebelumnya tidak ditemukan kesalahan pada LKPD pertemuan keempat tersebut.

4. Adapun dari hasil dan pembahasan peneliti terhadap desain didaktis materi segiempat di atas, peneliti mengajukan beberapa saran sebagai bahan pertimbangan dalam melaksanakan penelitian selanjutnya, diantaranya adalah: (1)Usulan desain didaktis dapat diterapkan untuk meminimalisir munculnya learning obstacle muncul kembali pada pembelajaran materi segiempat segiempat; (2)Untuk guru, dalam menyusun desain didaktis diharapkan untuk lebih teliti lagi seperti pada penyesuaian soal bergambar, kesesuaian penilaian yang dilakukan, pemaparan kunci jawaban dengan soal yang ada pada RPP atau LKPD, dan jika memungkinkan disarankan untuk dapat mengimplementasikan desain didaktisnya kepada siswa disekolah adapun jika tidak memungkinkan karena alasan tersentu dapat menggunakan sisa disekitar tempat tinggal untuk pengujian desain didaktis tersebut. Selain itu, disarankan juga kepada guru untuk memberikan sumber belajar yang mencukupi siswa dalam memahami konsep dari materi yang diajarkan, tidak hanya mengandalkan buku matematika yang diterbitkan oleh pemerintah atau yang ada disekolah saja tetapi dapat juga menggunakan sumber lain seperti alat peraga buatan guru, materi ajar dari internet, atau bahkan lingkungan sekitar siswa yang memungkinkan dan daat dijadikan sarana pembelajaran; dan (3)Untuk peneliti selanjutnya yang akan melakukan penelitian terkait analisis desain didaktis dalam bentuk yang sama yaitu RPP dan LKPD atau pun dalam bentuk yang berbeda sesuai dengan kebutuhan dan sumber penyusunan yang menjadi acuan peneliti, diharapkan untuk dapat menganalisis desain didaktis dengan lebih teliti lagi sehingga apabila ditemukan kekurangan yang dapat menimbulkan atau memunculkan learning obstacle dari desain didaktis tersebut dapat diperbaiki sebagaimana mestinya sehingga desain didaktis dapat digunakan untuk kegiatan pembelajaran yang sesuai dengan tujuan dan harapan yang diinginkan. Adapun apabila peneliti menganalisis desain idaktis yang disusun oleh peneliti lain, ada baik untuk memperhatikan bahwa desain didaktis yang digunakan sudah diimplementasikan atau tidak oleh penyusunnya dan apabila belum diuji cobakan maka peneiliti dapat berdiskusi dengan guru untuk melakukan uji coba desain didaktis untuk 
kepentingan bersama dan untuk mendapatkan hasil yang relevan dan akurat dari fungsi desain didaktis tersebut.

\section{E. Ucapan Terimakasih}

Dengan mengucapkan puji syukur kehadiran Allah SWT yang Maha Pengasih lagi Maha Penyayang. Alhamdulillah berkat taufiq dan hidayah-Nya, penulis dapat menyelesaikan tugas akhir atau skripsi ini dengan baik. Penulis menyadari bahwa tanpa dukungan dari berbagai pihak, skripsi ini tidak akan selesai dengan baik. Oleh karena, itu penulis mengucapkan banyak terimakasih dan penghargaan yang setinggi-tingginya kepada:

1. Bapak Dr. Dikdik Harjadi, S.E, M.Si selaku Rektor Universitas Kuningan beserta seluruh staff.

2. Ibu Yeyen Suryani, M.Pd selaku Dekan Fakultas Keguruan dan Ilmu Pendidikan Universitas Kuningan.

3. Bapak Mohamad Riyadi, M.Si selaku ketua Program Pendidikan Matematika beserta seluruh Dosen Pendidikan Matematika Universitas Kuningan yang telah memberikan ilmu dan bimbingan selama penulis menempuh pendidikan.

4. Ibu Sumarni, M.Pd selaku dosen pembimbing I yang telah membimbing, memberi dukungan dan memotivasi penulis dalam menyelesaikan tugas akhir.

5. Ibu Nuranita Adiastuty, M.pd selaku dosen pembimbing II yang telah membimbing, memberikan dukungan serta memotivasi penulis dalam menyelesaikan tugas akhir.

6. Orang tua tersayang dan seluruh keluarga yang telah banyak memberikan arahan, dukungan, semangat dan senantiasa selalu mendoakan keberhasilan penulis selama menempuh pendidikan di perguruan tinggi ini.

7. Rekan-rekan mahasiswa Program Studi Pendidikan Matematika Angkatan 2016 yang telah banyak membantu dan memberikan motivasi kepada penulis selama mengikuti perkuliahan maupun penyusunan skripsi.

8. Keluarga besar SMP Negeri 1 Kramatmulya yang telah memberikan masukan dan semangat kepada penulis selama kegiatan Praktek Keterampilan Mengajar (PKM) maupun penyusunan skripsi ini.

Akhir kata, semoga Allah SWT memberikan imbalan yang berlipat ganda atas bantuan yang diberikan kepada penulis dalam menyelesaikan tugas akhir ini.

\section{DAFTAR PUSTAKA}

Brousseau, G. (2002). Theory of Didactical Situations in Mathematics, Edited and translated by Nicolas Balacheff, Martin Cooper, Rosamund Sutherland and Virginia Warfield, edition Mathematics Education Library. Mathematics Education Library, Kluwer Academic Publishers, The Netherlands.

Burger, W. F., \& Shaughnessy, J. M. (1986). Characterizing the van Hiele levels of development in geometry. Journal for research in mathematics education, 31-48.

Choridah, D. T. (2013). Peran pembelajaran berbasis masalah untuk meningkatkan kemampuan komunikasi dan berpikir kreatif serta disposisi matematis siswa SMA. Infinity Journal, 2(2), 194-202.

D'amore, B. (2008). Epistemology, didactics of mathematics and teaching practices. Mediterranean Journal for Research in Mathematics Education, 7(1), 1-22. 
Departemen Pendidikan Nasional. (2003). Undang-undang Nomor 20 Tahun 2003 Tentang Sistem Pendidikan Nasional : Depdiknas.

Evayanti, M. (2013). Desain Didaktis Konsep Luas Daerah Jajargenjang Pada Pembelajaran Matematika Sekolah Menengah Pertama (SMP). (Doctoral dissertation, Universitas Pendidikan Indonesia).

Fitriyani, H., Widodo, S. A., \& Hendroanto, A. (2018). Students'geometric Thinking Based On Van Hiele's Theory. Infinity Journal, 7(1), 55-60.

Halat, E., Jakubowski, E., \& Aydin, N. (2008). Reform-based curriculum and motivation in geometry. Eurasia Journal of Mathematics, Science and Technology Education, 4(3), 285-292.

Kurniawan, M. F., \& Setyaningsih, N. (2016). Analisis Lembar Kerja Siswa Mata Pelajaran Matematika Kelas VII Ditinjau Dari Taksonomi Bloom Revisi (Doctoral dissertation, Universitas Muhammadiyah Surakarta).

Miles, M. B., \& Huberman, A. M. (1994). Qualitative data analysis: An expanded sourcebook. sage.

Nuroniah, S. (2014). Desain Didaktis Konsep Luas Daerah Segitiga dan Segiempat Pada Pembelajaran Matematika di Sekolah Menengah Pertama berdasarkan learning obstacle dan learning trajectory. (Doctoral dissertation, Universitas Pendidikan Indonesia).

Nurrahmi, H. (2014). Desain didaktis sifat-sifat Segiempat pada Pembelajaran Matematika di Sekolah Menengah Pertama berdasarkan Learning Obstacle dan Learning Trajectory. (Doctoral dissertation, Universitas Pendidikan Indonesia).

Permen. (2006). "Standar Kompetensi Lulusan Untuk Satuan Pendidikan Dasar dan Menengah": Peraturan No.23

Rusman. (2011). Model-model pembelajaran: Mengembangkan profesionalisme guru. Rajawali Pers/PT Raja Grafindo Persada.

Suryadi, D. (2010). Menciptakan proses belajar aktif: kajian dari sudut pandang teori belajar dan teori didaktis. Bandung : Tidak Diterbitkan.

Wahyudin, P. (2008). Pembelajaran dan model-model pembelajaran. Diktat Kuliah.

Wulansari. (2017). "Upaya Peningkatan Keaktifan Dan Prestasi Belajar Dengan Model Pembelajaran Problem Based Learning (PBL) Pada Mata Pelajaran Elektronika Dasar Siswa Kelas X Kompetensi Keahlian Teknik Elektronika Industri Di SMK Negeri 3 Boyolangu Kabupaten Tulungagung”. Skripsi Universitas Negeri Yogyakarta.

ZAKARIA, F. W. (2016). Analisis Rencana Pelaksanaan Pembelajaran Pada Mata Pelajaran Seni Budaya Untuk Bidang Seni Musik Kelas 9 Semester Ganjil Di Smp Negeri 6 Cimahi Tahun Ajaran 2015/2016 Femi Wahyu Zakaria 106040054 (Doctoral dissertation, Seni Musik). 